\title{
A REPLY
}

\section{Akhil Reed Amar}

It is an honor to have my two-tier thesis examined and operated upon by two such experienced legal surgeons as Daniel Meltzer and Martin Redish. Alas, the prognosis, according to these two juris doctors, is none too good. Redish pronounces the thesis virtually dead on arrival; ${ }^{1}$ Meltzer, though more cautious and less colorful, is in the end not very encouraging. ${ }^{2}$ But, dear reader, do not be fooled. The two-tier thesis is very much alive (and kicking).

\section{The Question}

It would be rather silly to claim that the two-tier thesis provides an undeniably perfect interpretive account of all possible data-constitutional text, history, structure, case law, etc. Rather, my claim, in $1985^{3}$ and now, ${ }^{4}$ has always been that the thesis, however "problematic" and "imperfect," provides a far better-more plausible, more coherent, more careful, more sensible, more explanatory, more satisfying-account of article III than any of its interpretive competitors. ${ }^{5}$ To meet this claim, Meltzer and Redish need to show that, by the same standards they apply to my thesis, their own proferred alternatives have fewer holes and more explanatory power. In short, the key question is comparative. In what follows, I shall try to condense and summarize the data, avoiding as much repetition as possible. In virtually every category, it will appear that the two-tier thesis is better.

1 See Redish, Text, Structure and Common Sense in the Interpretation of Article III, 138 U. PA. L. REv. 1633 (1990). (1990).

2 See Meltzer, The History and Structure of Article III, 138 U. PA. L. REv. 1569

3 Amar, A Neo-Federalist View of Article III: Separating the Two-Tiers of Federal Jurisdiction, 65 B.U.L. Rev. 205 (1985) [hereinafter Amar, A Neo-Federalist View].

4 Amar, The Two-Tiered Structure of the Judiciary Act of 1789, 138 U. PA. L. REv. 1499 (1990). 1546.

5 See Amar, A Neo-Federalist View, supra note 3, at 230 n.86; Amar, supra note 4, at 


\section{The Evidence}

\section{A. Text}

The two-tier thesis pays careful attention to many of article III's words and phrases-“judicial power," "of the United States," "vested," "judges," "arising under," "admiralty and maritime" and so on-but places special emphasis on the words "shall" and "all." Redish and Meltzer both disagree with this emphasis.

\section{Redish}

Redish's most colorful claim-that my textual analysis is "internally inconsistent"6 - rests on a misstatement of my argument. He claims that because I would allow Congress to remove various second tier controversies frorn federal courts altogether, I somehow undercut my argument that the word "shall" in the "shall be vested" and "shall extend" clauses is mandatory. ${ }^{7}$ Redish's claim is a nonsequitur. I simply read article III to require that the judicial power "shall be vested" in federal courts; and that such power "shall extend," in either original or appellate form, to "all" cases in the first tier; and to a few, some, or all, as Congress chooses, "controversies" in the second tier. In both places, under my theory, "shall" obviously means "shall"- that is, "must." Indeed, precisely because I take "shall" as strictly mandatory, I have explicitly noted that "arguably federal courts must have the power to hear some minuscule subset of" each second tier category in order to satisfy the command that "the judicial power shall extend to [at least two] controversies in each category." 8 Yet since "any such restriction on congressional power would be . . trivial," for expository ease it is easier to speak "as if Congress could abolish all jurisdiction in these categories."9

To be sure, article III does not literally read the way I have rendered it above. I have interpolated the italicized words a few, some, or

\footnotetext{
6 Redish, supra note 1 , at 1634.

7 See id. at 1639-41.

8 Amar, A Neo-Federalist View, supra note 3, at 240 n.119 (emphasis added and insert in original).

9 Id. Despite Redish's attempted sleight of hand, Redish, supra note 1, at 1641 n.29, the "shall be vested" clause does not tell us which cases fall within the judicial power. For example, must state law cases between co-citizens be vested in federal courts? The answer to this must come from the "shall extend" clause, which defines the scope of what must be vested. And as I have explained in the text, this language is two-tiered.
} 
all, as Congress chooses in the place of a textual lacuna. But some interpolation is unavoidable. In his more colorful moments, Redish seems to argue that anyone who takes the text seriously must somehow interpolate "all" here. ${ }^{10}$ But there is an obvious problem with that approach, as Redish himself recognizes sotto voce: to interpolate "all" seems to do violence to the carefully selective use of "all" in article III. (Put another way, to a formalist like Redish, automatic interpolation of "all" seems to violate the maxim of expressio unius.)

This point is at the very heart of my textual argument, yet Redish contents himself with a single and breezy footnote on the problem. ${ }^{11}$ Apart from reiterating his willingness to interpolate "all"which does not avoid the textual problem, and requires him to presume that the selective use of "all" is meaningless (a presumption contrary to first principles of faithful textual interpretation)-Redish suggests that the Constitution itself provides for an unspecified, but nevertheless fixed amount (short of "all") of jurisdiction in second tier controversies. I, on the other hand, argue that precisely because the Constitution does not specify this amount, in sharp contradistinction to the word "all" in the first tier, the Constitution gives Congress the power to decide how little or how much second tier jurisdiction to vest. My argument is carefully grounded in the precise language of the necessary and proper clause, ${ }^{12}$ in the interplay between that clause and the language of article III, ${ }^{13}$ and in the plain language of the leading Supreme Court case on the issue, Rhode Island v. Massachusetts, ${ }^{14}$ where the Taney Court explicitly rejected a Redish-like argument of counsel at oral argument in favor of my necessary and proper clause approach. ${ }^{15}$ Because Redish neither mentions nor addresses any of this, his argument never gets off the ground. My argument here also rests in large part on dramatic evi-

10 See Redish, supra note 1 , at 1639-41.

11 See id. at 1640 n.28.

12 See Amar, A Neo-Federalist View, supra note 3, at 229-30, 254-55 n.160; Amar, Marbury, Section 13, and the Original Jurisdiction of the Supreme Court, 56 U. CHI. L. REv. 443, 480-83 (1989) [hereinafter Amar, Section 13].

13 See Amar, Section 13, supra note 12, at 481-83 \& nn.176-84.

1437 U.S. (12 Pet.) 657 (1838).

15 See id. at 672-73 (Redish-like claim at oral argument); id. at 721 (Court rejection in favor of my approach, explicitly invoking necessary and proper clause). For full quotations and more discussion, see Amar, Section 13, supra note 12, at 48485. Professor Meltzer's account of this case fails to capture the meaning of this exchange, and thus misses the case's significance. See Meltzer, supra note 2, at 1628 n.228. Here, as elsewhere, the interested reader would do well to consult my initial formulation. See Amar, Section 13, supra note 12, at 481-85. 
dence from the Philadelphia Convention, which, as we shall see below, ${ }^{16}$ Redish ignores.

Despite his lapses and inaccuracies, Redish does make one serious textual point: the language of article III is considerably more awkward in expressing the meaning I attribute to it than alternative language would be. For example, it would have been far clearer for the framers to have explicitly interposed the italicized phrase I interpolated before the word "controversies." Thus while Redish errs in claiming that my reading is "internally inconsistent," he does correctly identify the reading's awkwardness. But as with much else, awkwardness is a comparative concept. Is it not more awkward to presume that the two-tiered language has no meaning-even when, as we shall see below, that language is buttressed by powerful historical and structural arguments?

What's more, if the framers had truly intended for Congress to have the kind of plenary jurisdiction stripping power that Redish claims, the language they chose is even more awkward. Whereas my reading fills in an interpretive gap where some implicit gap-filling is unavoidable, Redish's reading rewrites article III from start to finish. Redish himself unwittingly dramatizes this point himself by drafting language that looks profoundly different from article III: "All of the judicial power, including the authority to interpret and enforce this constitution, shall be vested in the judiciary, except the legislature may make exceptions to or impose limitations on that authority, as it so desires." 17 Unlike the words of this passage, article III's commands that the judicial power "shall be vested" in federal courts and "shall extend to all cases" in certain categories are not expressly limited by the exceptions clause. Only the Supreme Court's appellate juridiction, not the judicial power of the United States, is so limited. Redish must thus twist the exceptions language into an implied repeal of unambiguous prior commands. This is surely awkward, not to mention in violation of standard interpretive canons disfavoring repeals by implication. ${ }^{18}$

16 See infra text accompanying notes 34-47.

17 Redish, supra note 1 , at 1635.

18 Elsewhere, Redish again argues for repeal by implication by suggesting that the due process clause radically altered congressional power under article III to oust state court federal question jurisdiction, id. at 1648 n.54, while citing no history to show that the due process framers thought they were in any way changing article III's allocational rules. Redish's newly'-voiced position stands in sharp contrast to the "traditional" Hart position that due process principles requiring that at least state courts be open to hear federal claims were implicit in article III. Although I have in the past criticized Hart's precise formulation, see Amar, A Neo-Federalist View, supra 
Put another way, if bifurcation is rejected, and "all" is interpolated before "controversies" in the second tier, the obviously best reading would not be Redish's unitary permissive thesis, but Professor Clinton's unitary mandatory approach (which Redish does not even mention, much less engage). ${ }^{19}$ Under Clinton's approach, precisely because "shall" means "shall" and is not explicitly qualified by the exceptions clause, all nine jurisdictional categories would have to be vested, at least on appeal, in federal courts. The "exceptions" clause would operate only to allow Congress to shift Supreme Court appellate jurisdiction to some other federal court. Redish fails to grasp that the two-tiered reading actually gives Congress more power than it would have under the most plausible unitary approach (many of whose textual, structural and historical foundations also support the two-tier approach).

Again: if, as Redish concedes, the language of the exceptions clause does not modify the "shall" in the clause setting out the Supreme Court's original jurisdiction, how can it modify the mandatory character of the "shall be vested" and "shall extend" clauses? If, as Redish has explicitly argued in the past, ${ }^{20}$ the Court's original jurisdiction cannot be modified because "shall" means "must" in the "shall be vested" and "shall have original jurisdiction" clauses, why is the same not true of the "shall extend to all cases" mandate? Redish never engages these questions, which I explicitly posed in both of the essays he now dismisses ${ }^{21}$ (and in a third he disregards). ${ }^{22}$ It is of course also revealing that Redish's rewriting of article III conveniently sidesteps the original jurisdiction issue.

note 3 , at $226 \mathrm{n} .81$, in retrospect Hart's view seems much more plausible than Redish's clause-bound and a-structural approach. Contrary to Redish's intimations, the framers of the Bill of Rights explicitly stated that many of their amendments did not alter existing constitutional rules, but simply declared and clarified them. See, e.g., U.S. Const. amend. X; 2 DocumentaRy History of the Constitution 321 (G.P.O. 1901) (congressional resolution accompanying Bill of Rights describing them as "declaratory" as well as "restrictive").

19 See generally, Clinton, A Mandatory View of Federal Court Jurisdiction: A Guided Quest for the Original Understanding of Article III, 132 U. PA. L. REv. 741 (1984). For more discussion of this thesis, see Amar, supra note 4, at 1506-08, 1519-22, 1534-35, 1549-53, 1564.

20 See Amar, supra note 4, at 1522-24 and sources cited therein.

21 Amar, A Neo-Federalist View, supra note 3, at 239 n.118; Amar, supra note 4, at 1522-25.

22 Amar, Section 13, supra note 12, at 487. While the present essay was in press, Professor Redish did add a brief discussion of the original jurisdiction issue. See Redish, supra note 1 , at 1637 n.24. I, of course, agree that the purpose of an "exception" is to qualify a rule-but the question is, which rule? Plainly, the words of the exceptions clause qualify the otherwise mandatory command that the Supreme 
In the end, the reader is entitled to ask of Redish, "Whose Constitution are you talking about, Utopia's or ours?"23 But Redish is not content simply to rewrite article III. He also insists on rewriting my theory, knocking down straw arguments I never made, and never addressing the serious ones I did. He does make one good point"Had the framers intended the result urged by Professor Amar, they could have said so" more clearly ${ }^{24}$-but as a comparative matter, the point proves too much, for the same of course is true for every other reading of article III, especially Redish's.

\section{Meltzer}

Professor Meltzer's essiay is far more careful (if less colorful), but in the end no more satisfying in its textual exegesis. Meltzer recognizes that any claim that article III's two-tiered language is meaningless is unattractive, so he attempts to come up with a counterthesis that focuses attention on the fact that in the first tier article III uses the word "cases," but in the second, "controversies" (a fact I also explicitly noted and discussed in 1985). ${ }^{25}$ Meltzer argues that "cases" encompass both criminal and civil disputes, but "controversies" only the latter. ${ }^{26}$ There are three big problems here. First, as we shall see below, there is very little historical support for this claim. If the issue is a comparative one, there is far less support for Meltzer's thesis than for mine in the Philadelphia Convention records, in the ratification debates, in the text and legislative history of the Judiciary Acts of 1789 and 1801, and in early Supreme Court case law. Meltzer's apparent willingness to sign onto the civil/criminal distinction, but not the mandatory/permissive one is emblematic of a subtle but pervasive double standard that runs throughout his essay. (And speaking of clouble standards, I cannot resist making the "perhaps too easy"27 point that if the term "controversies" sim-

Court "shall have appellate jurisdiction" in "all" non-original cases-thus illustrating that "shall" and "all" are here again used in their plain meaning sense. See Amar, $A$ Neo-Federalist View, supra note 3 , at 239 n.118, 242. The words of the clause do not, however, repeal the more global command that "the judicial power shall extend to all" first tier cases.

${ }^{23}$ Cf. Hart, The Power of Congriss to Limit the Jurisdiction of Federal Courts: An Exercise in Dialectic, 66 HaRv. L. REv. 1362, 1372 (1953). I am using "Utopia" here in its literal sense-i.e. "no place."

24 Redish, supra note 1 , at 1637.

25 See Amar, $A$ Neo-Federalist View, supra note 3, at 244 n.128 (noting but discounting interpretation of language as tracking civil/criminal distinction).

26 See Meltzer, supra note 2, at 1574-76.

27 Cf. id. at 1604. 
ply means "civil cases" the framers could have said so with great ease.)

Second, and more damning, the civil/criminal distinction, whether or not ultimately persuasive, is wholly irrelevant. So what if "cases" and "controversies" mean different things? How does that account for the fact that the judicial power shall extend to "all" [criminal and civil] cases in the first tier, but not necessarily all [civil] controversies in the second? To his great credit, Meltzer is candid enough to admit that his approach renders the selective use of the word "all"28 wholly redundant of the case/controversy distinctionredundant, I might add, in a manner awkward enough to make Yogi Berra wince. Isn't it less strained to follow plain meaning and read "all" as adding something above and beyond whatever case/controversy distinction may exist? (The Martin Court thought so even without the benefit of various then-unreleased evidence from Philadelphia that, as we shall see below, strongly supports Martin's reading.) In the end, Meltzer is willing here to let his own theory wriggle off the hook far too quickly-"it remains possible that 'all" " is both awkward and redundant ${ }^{29}$ — while holding my thesis to a considerably higher standard.

Finally, even if Meltzer were to have a good case against bifurcation, this hardly leads to his own "traditional" unitary permissive thesis rather than Professor Clinton's unitary mandatory approach. Under Meltzer's view, why is there no requirement that federal courts have the last word in all first tier cases, criminal and civil, and all civil cases in the second tier? Meltzer says that "one can easily read ... 'shall be vested" " to mean "may (rather than must),"30 but this slide from the text's plain meaning is "easy" only if one blithely ignores the vast bulk of historical and structural arguments that both Clinton and I make. ${ }^{31}$ So too with Meltzer's reading of "shall extend"-which runs contrary to the great weight of federalist argument featured in my work and Clinton's. (Meltzer's support consists of self-serving and conclusory statements by a single rather obscure anti-federalist in the first Congress. ${ }^{32}$ Here too, a double standard seems to apply.) Nor can Meltzer draw much comfort from the

28 See id. at 1575.

29 Id. (emphasis added); $c$. id. at $1573 \mathrm{n} .14$ (similar formulation).

30 Id. at 1596-97; see also id. at 1573 n.14.

31 See, e.g., Amar, supra note 4, at 1525 n.80 (citing sources). See generally Clinton, supra note 19.

32 See Meltzer, supra note 2, at 1573-74 nn.14-15 (quoting Michael Jenifer Stone). 
exceptions clause for, as we have seen, the clause in no way repeals the "shall be vested" and "shall extend" mandates. Indeed, Meltzer himself candidly admits (in sharp contrast to Redish) that there is little evidence from Philadelphia enabling the tiny clause to bear all the weight "traditionalists" heap upon it. ${ }^{33}$ (Under both Clinton's approach and my own, the clause of course needs to bear far less weight for it only authorizes shifting federal question and admiralty among article III officers.)

\section{B. History}

\section{The Philadelphia Convention}

To fully know a text, one must understand its context. The immediate context generating the two-tiered text of article III was of course the Philadelphia Convention-in particular its five man Committee of Detail, appointed to integrate the Convention's resolutions into a full working draft Constitution. It is in this Committee that the two-tiered text of article III took shape. The two-tier thesis draws support from myriad bits of evidence from Philadelphia, but focuses especially on four items:

*1. After considerable preliminary discussion, the Convention ultimately adopted as its final charge to the Committee of Detail a resolution proposed by Madison: "the jurisdiction [of the national judiciary] shall extend to all cases arising under the Natl. laws: And to such other questions as may involve the Natl. peace \& harmony." 34

*2. The first major Committee of Detail draft, composed by Edmund Randolph with emendations by John Rutledge (indicated in brackets) fleshed out the Convention's resolution as follows:

The jurisdiction of the supreme tribunal shall extend

1. to all cases, arising under laws passed by the general [Legislature]

2. to impeachments of officers, and

3. to such other cases as the national legislature may assign, as involving the national peace and harmony, in the collection of the revenue in disputes between citizens of different states

33 See id. at 1610.

342 The Records of the Federal Convention of 1787, at 46 (M. Farrand ed. 1937). The resolution's wording is taken from the notes of its sponsor, James Madison. 
[in disputes between a State \& a Citizen or Citizens of another State]

in disputes between different states; and

in disputes, in which subjects or citizens of other countries are concerned

[\& in Cases of Admiralty Jurisdn $]^{35}$

*3. The next major draft of the Committee, in James Wilson's hand, preserved the basic two-tiered structure of its predecessor, but did so through the selective use of the word "all." This draft bears a striking resemblance to the ultimate Committee report, and in turn, the eventual language of article III:

The Jurisdiction of the Supreme (National) Court shall extend to all Cases arising under Laws passed by the Legislature of the United States; to all Cases affecting Ambassadors (and other) [other] public Ministers [\& Consuls], to the Trial of Impeachments of Officers of the United States; to all Cases of Admiralty and Maritime Jurisdiction; to Controversies between [States-except those wh. regard Jurisdn or Territory,-betwn] a State and a Citizen or Citizens of another State, between Citizens of different States and between [a State or the] Citizens (of any of the States) [thereof] and foreign States, Citizens or Subjects. ${ }^{36}$

*4. After adopting (with minor modifications) the Committee of Detail's language, the Convention carefully modified the clause setting out the Supreme Court's original jurisdiction, adding the single word "all" before ambassador cases, but not state party cases, thereby bringing the clause into strict conformity with the selective use of "all" in the jurisdictional menu. ${ }^{37}$

On the basis of all this (and other evidence from Philadelphia), I presented in 1985 the following (hi)story: ${ }^{38}$ Madison's final Convention resolution (*1) strongly anticipated a two-tier approach, in singling out, and giving literal primacy to, arising under jurisdiction (the coextensiveness principle) and in strongly hinting that jurisdiction must ("shall") extend to all arising under cases, but not necessarily "all" cases in other categories ("such questions as may . . ."). The Committee of Detail tried to implement this rather broad resolution by enumerating specific categories of judicial power, just as

$35 \mathrm{Id}$. at $146-47$.

36 Id. at 172-73 (inserts in original).

37 Compare id. at 576 (Committee of Style draft) with id. at 661 (final draft).

38 See, e.g., Amar, A Neo-Federalist View, supra note 3, at 242-45. For a brief discussion of the impeachment issue flagged by Meltzer, see Meltzer, supra note 2, at 1580 n.35, see Amar, A Neo-Federalist View, supra note 3, at 244 n.128. 
they tried to enumerate specific categories of legislative power in language that would eventually become article $I$, section 8 . They obviously read Madison's resolution $\left({ }^{*} 1\right)$ as two-tiered, for in their first draft $(* 2)$ they required that jurisdiction "shall extend" to "all" proto-arising under cases, but only to "such other cases as the legislature may assign" in other areas. In the second tier, we see obvious prototypes of the second tier, party-defined "controversies" of the final version of article III. Ass is often true of first drafts, there were some glaring omissions; when Rutledge remembered admiralty, whose significance and appropriateness were almost universally recognized, he scribbled language on the bottom of the page, without integrating it into the carefully two-tiered structure. The task of integration fell to James Wilson, whose Committee draft (*3) preserved the plainly two-tiered structure of its predecessor (*2) through the selective use of the word "all." There is of course a striking correspondence between, on the one hand, Wilson's first tier ("shall extend to all cases") and the explicitly mandatory language (ditto) in the Randolph-Rutledge draft; and on the other, between the categories in Wilson's second tier ("controversies" not preceded by "all") and those in the explicitly permissive tier ("such other cases as the legislature may assign") in the earlier draft. To be sure, Wilson did some substantive rearranging-he folded admiralty into the first (mandatory) tier, and added ambassador cases, apparently in an effort to integrate certain aspects of a plan authored by William Paterson, which he also had before him. Nevertheless, to juxtapose the two Committee drafts $(* 2$ and $* 3)$ is to see dramatic evidence that the selective use of the word "all" was introduced to preserve (if somewhat awkwardly) the plain distinction between mandatory and permissive tiers. The Convention adopted this two-tiered language, and later showed its appreciation of this key word by selectively adding it to the original jurisdiction clause so as to render it in painstaking conformity with the two-tiered language of the jurisdictional menu (*4).

How do Meltzer and Redish deal with all of this? Redish simply ignores it, and (after thus shielding it from view) proclaims my thesis "wholly result-oriented [and] unsupported," "totally devoid of meaningful historical supporl:," "complete[ly]" lacking any "contemporaneous" historical evidence, and "at odds with . . . the intent of those who drafted" article III. ${ }^{39}$ This may make for fun prose, but as serious scholarship, it just will not do. 
Meltzer's approach is more careful but in the end not much more convincing. He quotes only $* 1$ and $* 2$ and fleetingly mentions $* 3$ and $* 4$, but treats each bit in isolation. Thus, he argues that, taken alone, Madison's resolution is thin evidence of bifurcation. ${ }^{40}$ But when juxtaposed with the Randolph-Rutledge draft-which Meltzer tucks away in a footnote three pages later ${ }^{4}$-Madison's resolution looks rather different, and quite dramatic. Look again at how the draft carefully invokes Madison's language in its explicitly two-tiered structure. In the mandatory tier, jurisdiction "shall extend to all cases arising under" national laws, but in the permissive tier, only to "such other cases, as . . may . . involv[e] the national peace and harmony."

Meltzer's minimization of this draft also obscures the otherwise obvious fact that, contrary to his "easy" assertions, the framers used "shall extend" in a mandatory sense: "shall" means "shall," not "may," and "extend" means just that, not "have the capability [if Congress chooses]" as Meltzer suggests. Other evidence from Philadelphia, both before and after the Randolph-Rutledge draft, only confirms this point. ${ }^{42}$

Meltzer of course also nowhere juxtaposes the undeniably twotiered Randolph-Rutledge draft (*2) with Wilson's draft $\left({ }^{*} 3\right)$, where the selective use of "all" made its first appearance in Committee; nor does he concentrate on the subsequent history of "all" in the Convention (*4). But taken as a whole (rather than in a divide-and-conquer fashion), items $* 1-* 4$ seem to me rather powerful evidence for my reading of the selective use of "all." It is thus odd to see Meltzer stress that "The short of the matter is that Amar has not identified any speech at the Convention ... debates that articulated a distinction between mandatory and permissive jurisdictions." 43

40 See Meltzer, supra note 2, at 1577-78.

41 See id. at 1580 n.35.

42 See supra note 31 and sources cited therein. Meltzer nowhere addresses this evidence.

43 Meltzer, supra note 2, at 1578-79. Even if technically true, Meltzer's statement is misleading, especially because he only selectively presents the (hi)story I offered. But the statement is problematic in even its narrowest sense. Members of the Committee of Detail surely were participants at Philadelphia; surely they discussed and debated things, in Committee and beyond; and surely the drafts I identified are evidence of views they articulated. Now, drafts are not verbatim transcripts of speeches, but neither are Madison's notes. As the key language of article III was forged in this Committee, items $\star 2$ and $* 3$ are very substantial evidence indeed, and all the more so because Madison's notes preserve little evidence of whatever subsequent Convention discussion may have occurred. Here, as elsewhere, it is dangerous to draw strong inferences from "silence" alone, as do both Meltzer and Redish. The "record" is "silent" on many issues because Madison's notes are profoundly incomplete. See 
Meltzer further complicates matters by introducing lots of extraneous items-from drafts that played at best bit parts at Philadelphia (and appear to have had little or no impact on the Committee of Detail), from early discussions that occured before principles and priorities were identified and refined, and so on. ${ }^{44}$ What results is a rather open and indeterminate narrative. If Meltzer's aim is simply. to show that everything was and is up for grabs, this is, of course, a clever strategy.

But I take it this is not Meltzer's position. He knows that he must show why my account is less plausible than the "traditionalists'."45 Thus, in critiquing my view, he would have done well to set out the (hi)story as I set it out, and show why I'm wrong. But even if he did this (which he didn't), he would then need to present an affirmative focussed counternarrative that shows that the "traditional" reading is more consistent with the data. Where, for example, is the evidence that the framers believed that politically dependent state courts could sit as the last word in arising under and admiralty cases ? $^{46}$ Or that these cases were less important than, say, ambassador and state-party cases (and thus subject to jurisdiction stripping in a way that the latter are not, according to "traditionalists")? Or that the key (and sole) distinction between the two tiers is the civil/criminal distinction? And so on.

If the game is comparative, here's how I score Philadelphia. (1) I claim "shall extend" is mandatory; Meltzer denies it. The evidence plainly supports my reading and Meltzer offers no evidence. (2) I claim that federal question and admiralty jurisdiction were of primary importance; Meltzer concedes the first, and himself provides considerable evidence for the second-but seems to deny the constitutional significance of both concessions. Meltzer quotes fragments suggesting that some delegates viewed state party controversies as important but points to no solid evidence that the Convention generally viewed these disputes as more important than-or even as on a par with-federal question and admiralty cases. By contrast, items ${ }^{*} 1-* 4$ all downplay state party cases and stress the first tier, especially "arising under" cases. (3) I claim that the word "all" is signifi-

Hutson, The Creation of the Constitution: The Integrity of the Documentary Record, 65 TEx. L. REv. 1 (1986).

44 See Meltzer, supra note 2, at 1577, 1580, 1582.

45 See id. at 1623.

46 In fact, a leading source on whom Meltzer relies explicitly concedes that the historical evidence from Philadelphia runs the other way. See infra text accompanying note 90. 
cant as a trigger between mandatory and permissive tiers; Meltzer disagrees. Items * 1-*4 strongly support my view, and Meltzer offers no affirmative evidence from any major draft or discussion that the selective use meant something different or nothing at all. (4) Meltzer claims that first tier "cases" are distinct from "controversies" in the second tier because the latter comprise only civil disputes; I claim this distinction lacks much historical support, and in any event is irrelevant. Meltzer offers absolutely no historical support for his distinction, whereas juxtaposition of Committee drafts $* 2$ and *3 strongly supports my view that the key distinction between the two tiers is the mandatory/permissive distinction.

One final note about Philadelphia. There is more-far morePhiladelphia support for my ideas (structural superiority, true parity, political safeguards, and so on) than I have been able to highlight here. There is simply not enough space to re-present everything here, and to show how much Meltzer and Redish omit. What I hope I have shown is that their accounts of Philadelphia, and their reports of my own Philadelphia evidence (or lack thereof) are, well, ... exaggerated.

\section{Ratification Debates}

During the ratification debates, although federal admiralty was uncontroversial and federalists forcefully argued for plenary arising under jurisdiction, "no part of the Federal jurisdiction . . . sustained so strong an attack from the Anti-Federalists, or ... received so weak a defense from the Federalists as diversity jurisdiction." ${ }^{247}$ In Pennsylvania, James Wilson, the author of the two-tiered text, delivered an influential defense of article III in which he carefully observed its two-tiered language even as he paraphrased other portions of article III. ${ }^{48}$ Meltzer and Redish point to no affirmative evidence that anyone during ratification thought that the selective use of "all" meant something different (or nothing at all), and what they do cite is a mixed bag. First, Meltzer invokes anti-federalists who attacked federal question jurisdiction, but doesn't cite a single leading federalist who agreed. ${ }^{49} \mathrm{My}$ theory, of course, sought to interpret article III from the perspective of federalists ${ }^{50}$ who wrote, understood, and

47 Warren, New Light on the History of the Federal Judiciary Act of 1789, 37 Harv. L. Rev. 49, 81-82 (1923); see also Amar, supra note 4, at 1508 n.23 (citing sources).

48 See Amar, supra note 4, at 1545 n.169 (citing sources).

49 See Meltzer, supra note 2, at 1583-84.

50 This should be obvious from the title of my 1985 essay. However, notwithstanding Redish's color commentary to the contrary, I did not, in a 
defended it, rather than those whose views were rejected in Philadelphia and the ratifying debates. Meltzer also cites various federalists (including Hamilton in The Federalist No. 80$)^{51}$ who seemed to lump together all nine categories, but as Robert Clinton has shown, ${ }^{52}$ their statements generally argue not for Meltzer's view, but for the unitary mandatory thesis. Once again, my critics' biggest point is that there is not much affirmative evidence here supporting the two-tier thesis, but once again, as a comparative point, the same is true for them. There is simply not a lot of evidence either way, because the jurisdiction-stripping issue did not receive careful and sustained attention. Silence alone does not argue one way or another.

Although I have little analytic stake in quibbling over Meltzer's civil/criminal distinction (since, even if correct, it is basically irrelevant), I note that Meltzer cites only a single source (from an antifederalist who was not at Pliladelphia), ${ }^{53}$ and even that source is at best suggestive. ${ }^{54}$ Once again, a double standard is at work.

\section{The Judiciary Act of 1789}

The First Judiciary Act is discussed at length in the preceding essays, so the evidence can be quickly summed up. Although various holes in ambassador jurisdiction are equally inconsistent with all theories of article III, certain possible holes in state party cases are concededly "problematic"55 for "traditionalists" but not for the two tier-thesis. ${ }^{56}$ Since Meltzer seems to concede the strength of my analysis of the savings clause, the only "hole" left results from possibly underinclusive language in section 25. Meltzer tries to make

\footnotetext{
"simplistic and superficial" manner "fallaciously view[] the framers as a monolithic group." Redish, supra note 1, at 1646; see also Amar, A Neo-Federalist View, supra note 3, at 230 n.86.

51 See Meltzer, supra note 2, at. 1580-82.

52 See, e.g., Clinton, supra note 19 , at 750, 829-37. So too with the work of Professor Holt, whom Meltzer also cites here.

53 Meltzer, supra note 2, at 1575.

54 Far from distinguishing "(ases" from "controversies," the very sentence Meltzer quotes equates these two words. And even if "Agrippa" did believe that citizen-citizen diversity jurisdiction was civil only, there is nothing here from which to infer that "Agrippa" thought the same was true for all other "controversy" categories, but not first tier "cases." Slightly sturdier, but still far from firm support for Meltzer's distinction comes from a source he does not cite. See 1 The Debates of the Several State Conventions con the Adoption of the Federal Constitution, 336 (J. Elliot ed. 1888) [hereinafter Elliot's Debates] (proposed amendments accompanying Rhode Island's 1790 ratification of Constitution).

55 Meltzer, supra note 2, at 1597 n.96, 1608 n.138.

56 See Amar, A Neo-Federalist View, supra note 3, at 254 n.160; Amar, supra note 4, at 1523 n.74; Amar, Section 13, supra note 12, at 478-88.
} 
much - too much - of this, but I don't see a big gap, if any. Meltzer's analysis places great weight on the limiting language of section 25, but I too, account for this language. ${ }^{57}$ In any event, even if section 25 was underinclusive, it was so in a way that reflected a quite plausible congressional reading of article III's "arising under" mandate. ${ }^{58}$

In the double standard department, Meltzer's own case/controversy theory is far more difficult to square with the plain words of the Act. Section 12 speaks clearly of "any action" but Meltzer after noting these words argues that they don't mean what they say-only civil actions were covered. ${ }^{59}$ But in every other place where the Act intended to limit jurisdiction to "civil" cases it used the word "civil."60 And nowhere in the Act's legislative history does Meltzer identify any hint of his suggested civil/criminal distinction. Nor does Meltzer or Redish invoke any other affirmative evidence that the members of the first Congress believed the selective use of the word "all" was meaningless. Although the legislative history I presented is not overwhelming, as a comparative matter; it seems far more solid than its alternatives.

\section{The Judiciary Act of 1801}

As the federalists had far more control over the Act of 1801 than its 1789 predecessor, the later Act may furnish a better vista onto the Federalist Constitution of 1787. The Act's text and structure could hardly be more explicitly two-tiered, ${ }^{61}$ and the legislative history features Abraham Nott's very clear statements about the selective use of the word "all."62 Redish and Meltzer offer no evidence whatsoever here.

57 See Amar, supra note 4, at 1530 n.101, 1539-40.

58 See id. at 1529.

59 See Meltzer, supra note 2, at 1576 n.23. Meltzer's arguments for this reading are not implausible. But if we have to choose between the civil/criminal and the mandatory/permissive distinctions, Meltzer's arguments here are less plausible than those I offer for my reading of "arising under" and $\$ 25$. See Amar, supra note 4, at 1529-33; $f f$. infra text accompanying note 60 . (In fact, of course, we need not choose only one, since my two-tier thesis can easily accommodate the view that article III also contains a civil/criminal distinction.)

60 See, e.g., Judiciary Act of 1789, ch. 20, § 9, 1 Stat. 73 ("civil cases"); id. § 11 ("suits of a civil nature"); id. $\S 17$ ("controversies of a civil nature"). Note also that the Act seems to use the words "causes" (i.e., "cases") and "controversies" indiscriminately.

61 See Amar, supra note 4, at 1534 n.114.

62 See id. at $1550-51$. 


\section{Early Case Law and Commentary}

Martin v. Hunter's Lessee, ${ }^{63}$ of course, supports the two-tier thesis far more than it does the "traditional" account. Later classic Marshall Court opinions and at least one early Taney Court decision echo Martin's two-tiered approach. ${ }^{64}$ To be sure, these echoes are not as resounding as Martin itself ${ }^{65}$-but why should they be, given that the Court had already spoken? Three basic points remain. First, all these cases explicitly bifurcate article III into the same two tiers Story identified in Martin. Second, none of them in any way criticizes or challenges Story's "easy" answer ${ }^{66}$ that the two tiers correspond to mandatory and permissive jurisdiction, respectively. Third, as a comparative matter, none of these cases remotely suggests that the only-or even a key-distinction between the tiers is Meltzer's civil/criminal distinction.

Distinguished extra-judicial commentary-from Marshall, Story, Kent and Buchanan ${ }^{67}$-offers even more powerful evidence. The last three sources invoke Martin by name and strongly underscore (often literally) its emphasis on the selective words "all cases." Meltzer does not discuss the forceful words of Kent and Buchanan, but he does try to downplay Story's and Marshall's comments. Judge for yourself:

Story:

[I] $\mathrm{t}$ is clear, from the language of the constitution, that, in one form or the other [i.e., original or appellate], it is absolutely obligatory upon Congress to vest all the jurisdiction in the national courts, in

6314 U.S. (1 Wheat.) 304 (1816).

64 See Amar, supra note 4, at 1513 n.37 (citing sources). By contrast, Meltzer can point only to a lone dissent in 1793 in support of his own civil/criminal distinction. See Meltzer, supra note 2, at 1575 n.20.

65 See Meltzer, supra note 2, at 1628 n.228. But see Osborn v. Bank of the United States, 22 U.S. (9 Wheat.) 738, 82.1-22 (1824) (Marshall, C.J.) (labelling first tier "most important class").

66 See Amar, supra note 4, at 1.502 .

67 See id. at 1513-14.

In this category, as elsewhere, there is less support for Meltzer's civil/criminal distinction. His main support comes from St. George Tucker, an anti-federalist whose son was in fact losing counsel in Martin, where he took the extreme position that Congress had no power to provide for Supreme Court review of state court federal question cases. Although these views may be severable from the issue at hand, they nevertheless cast doubt on the Tuckers' general reliability on issues of judicial federalism. See Meltzer, supra note 2, at 1575 n.18. 
that class of cases at least, where it has declared, that it shall extend to "all cases." 68

Marshall:

[Arising under cases] stood first in the minds of the framers .... The jurisdiction is expressly given [to federal courts] in the words "the judicial power shall extend to all cases arising under this constitution."

...

... [T] $]$ he words are "all cases" and I deny that the word "some" can be substituted for "all," or that the word "all," can be satisfied if any one case can be withdrawn from the jurisdiction of the court. 69

Consider the following dialogue:

Meltzer: Professor Gunther notes that in their correspondence neither Story nor Marshall suggested that repeal of section 25 would be unconstitutional. ${ }^{70}$

Amar: Of course it wouldn't if some other federal court review of state court federal question jurisdiction were substituted. But both of these passages seem clearly to require at least some federal court, no?

Meltzer: Story's passage, as you concede, is equivocal. ${ }^{71}$

Amar: Not whether at least first tier cases are mandatory. If there's any equivocation, it's between my theory and Clinton's even broader mandatory thesis. But you reject both, so any equivocation here-and I see less than you-is in any event wholly at odds with your "Tradition." Besides, what about Marshall?

Meltzer: He merely sought to establish that Congress could, but need not, give federal courts federal question jurisdiction. ${ }^{72}$

$683 \mathrm{~J}$. Story, Commentaries on the Constitution of the United States, $\S 1696$ (1833).

69 Marshall, A Friend of the Constitution, in John Marshald's Defense of McCulloch v. Maryland 204, 212-14 (G. Gunther ed. 1969).

70 Meltzer, supra note 2, at 1579 n.33. But see 2 W. Story, Life and LetTers of JosÉph STORY 49 (1851) (reprinting Letter from Joseph Story to Professor Ticknor (Jan. 27, 1831)). Story's letter states:

If the twenty-fifth section is repealed the Constitution is practically gone .... Pray read on the subject of the twenty-fifth section, the opinion of the Supreme Court in Hunter v. Martin .... It contains a full survey of the judicial power of the General Government and Chief Justice Marshall concurred in every word of it.

Id.

71 Meltzer, supra note 2, at 1579 n.33.

72 Id. at 1592-93. 
Amar: Huh? Where does he say that? He is obviously invoking here the analysis and logic of Martin (the Supreme Court opinion most obviously on point, decided only three years before), which speaks of congressional obligation. And he invokes the language of the Constitution, not section 25. In response to Spenser Roane's slashing constitutional critique of section 25, Marshall could have simply stressed Congress's power, not its duty. But as did Story in Martin (with Marshall concurring behind the scenes in "every word") ${ }^{73}$ Marshall explicitly meets Roane with the broad argument that "shall" and "all" mean what they say even though this argument was less moderate politically. What's more, two pages before his explicit invocation of the "all cases" language he says:

[T] he judicial is a co-ordinate department, created at the same time, and proceeding from the same source, with the legislative and executive departments .... Neither of these is a deputy of ... the other two.... On a judicial question, then, the judicial department is the government, and can alone exercise the judicial power of the United States. ${ }^{74}$

These passages (which again obviously echo Martin) also strongly support my coextensiveness analysis and show that your "easy" readings of "shall be vested" and "shall extend" are plain misreadings. And of course nothing here supports your own civil/criminal thesis.

\section{Structure}

This is hardly the place to rehearse the interconnected structural arguments underlying the two-tier thesis-arguments that I at least consider the thesis's greatest strength-but I do want to dispute Meltzer's claim that there is "mis-match" between these arguments and the thesis. First, Meltzer argues that coextensiveness cannot explain ambassador jurisdiction and notes that it is "striking" that I spend so little time discussing this category. ${ }^{75}$ The reason is simple: no one today denies that arnbassador jurisdiction is obligatory on Congress, so why spend a lot of time on the obvious? ${ }^{76}$ (Except, of course to note that if ambassador jurisdiction is obligatory, it's only because "shall" and "all" mean just that.)" Coextensiveness is an

\footnotetext{
73 See supra note 70.

74 Marshall, supra note 69, at 210.

75 See Meltzer, supra note 2, at 1582 n.39, 1614-15.

76 See Amar, supra note 4, at 1513.

77 See id. at 1524-25. Elsewhere, I have explored the origins of the ambassador clause in greater detail. See Amar, supra note 3, at 244 n.129.
} 
absolute limit on congressional power-a minimum condition of legitimacy-but hardly the only constitutional limit. When I say "the rule of law requires that every case arising under federal law, in law, equity, or admiralty, be within the ultimate jurisdiction of politically independent courts," I nowhere deny that other principles (e.g., respect for ambassadors) might require federal jurisdiction over other categories.

Meltzer's mis-match claim about how the political safeguards principle doesn't cover federal statutes also misses the point. ${ }^{78}$ I claim that in tandem, ${ }^{79}$ coextensiveness and political safeguards cover all "arising under" cases. Any divide-and-conquer attempt to isolate each one calls to mind the fellow who criticized tea because hot water is bland and a dry tea bag sticks to one's mouth. Meltzer comes closer to the mark when he claims that coextensiveness can't account for the mandatory nature of all admiralty cases. ${ }^{80}$ Elsewhere, I explain why I think he's wrong here using logic remarkably similar to what he invokes, when he tries to defend his own civil/criminal thesis. ${ }^{81}$ In any event, given that the rule of law is a minimal condition of legitimacy, if no discrimination among admiralty cases is permissible-and article III treats all admiralty as undifferentiated-the category as a whole must be mandatory.

Although Meltzer also tries to create a mis-match between the structural superiority principle and my overall thesis, mis-match exists only if we blur together two very different types of state court "bias," geographic parochialism and political dependence. In fact these two were quite different. State courts over the years might lose their localism, but not their lack of article III independence. They could become no better than article I judges-and for the framers, that wasn't good enough to satisfy the coextensiveness and political safeguard principles where federal rights were at issue. Coextensive-

78 See Meltzer, supra note 2, at 1615. Meltzer also tries to downplay the qualitative importance of various constitutional limitations on state government imposed by the original Constitution. See, e.g., id. at 1570, 1607 n.134. So too does Redish. See Redish, supra note 1, at 1645 n.45. For lots of evidence to the contrary, see Amar, $A$ Neo-Federalist View, supra note 3, at 208 n.9, 247 n.134; Amar, Of . Sovereignty and Federalism, 96 YALE L.J. 1440-41 (1987), and sources cited therein. These sources contain repeated statements by Madison undermining Meltzer's claims about him. The only other federalist Meltzer cites, Archibald Maclaine, also viewed federal court review of constitutional limits on states as vital. See 4 Ellıor's DeBates, supra note 54, at 172.

79 Amar, supra note 4, at 1511-13.

80 See Meltzer, supra note 2, at 1614.

81 See Amar, supra note 4, at 1512-13, 1526-27 \& n.85; $c$. Meltzer, supra note 2, at 1576 n.23. 
ness was an axiom ${ }^{82}$-a rule-of-law condition of legitimacy-and could not be waived by Congress.

Meltzer also tries to counter the true parity principle by arguing that the Supreme Court was expected to exercise appellate jurisdiction. ${ }^{83}$ But so were some lower federal courts—over both state and other federal courts. ${ }^{84}$ Meltzer invokes "uniformity," but nowhere explains why certain configurations of lower courts-say a National Tax Court, or a National Court of Appeals-couldn't achieve uniformity. Meltzer closes this section with a question: "Is there . . . a coherent basis for concluding, as Amar does, that article III does protect the supremacy of federal law (vis-a-vis the states and the federal political branches), but does not require uniformity?"85 Sure there is-especially if we stop focussing on (at most) microscopic holes in section 25, and instead look at the basic structure of the First Judiciary Act. No claims of federal right were given finally to state courts under section 25 (even under Meltzer's narrow reading of this section), but lower federal courts were allowed the last word in lots of critical federal cases-even at the expense of uniformity. For example, because of "exceptions" made in favor of lower federal courts, only these courts, and not the Supreme Court, ruled on the Alien and Sedition Acts during the new nation's first constitutional crisis.

In the end, despite Meltzer's best efforts, all my structural arguments remain intact, and firmly linked to my overall two-tier thesis.

\section{THE VERDICT}

My separation of the data into separate categories-text, history, structure, etc.-eases exposition but risks obscuring the rich inter-

82 See e.g., The Federalist No. 80, at 535 (J. Cooke ed. 1961) (A. Hamilton) ("If there be such things as political axioms, the propriety of the judicial power of a government being co-extensive with its legislative, may be ranked among the number."). For similar language of "natural," immutable, math-like laws of political "science" that the federalist children of the Enlightenment believed that they had discovered, see sources cited in Amar, supra note 4, at 1563-64 (describing coextensiveness as Platonic "essen[ce]" required by mathematical requirement of "indivisibility," and the "very Nature of the Thing," the violation of which is a "Solecism"). See generally The Federilist No. 9;" supra, at 51 (A. Hamilton) (invoking "science of politics"); id. No. 31, at 193-94 (A. Hamilton) (certain principles of government analogized to "maxims in geometry").

83 See Meltzer, supra note 2, at 1618-19. For further answers to Meltzer's uniformity question, see Amar, $A$ Neo-Federalist View, supra note 3 , at $220 \& \mathrm{n} .59,263$ \& n.189; Clinton, supra note 19 , at $753,778,832$.

84 See, e.g., Amar, A Neo-Federalst View, supra note 3, at 234.

85 Meltzer, supra note 2, at 1619. 
connections and synergies across categories. (For example, although the strongest arguments for bifurcation are structural, my exposition may seem to put more weight on the textual basis.) In my 1985 essay, I sought to illustrate these interconnections by presenting a detailed, integrated and coherent narrative. I do not believe I'm the only one who has done so. Professors Clinton and (to a somewhat lesser degree) Sager have in their own work presented similarly careful and holistic accounts. ${ }^{86}$

Although we disagree among ourselves about certain issues, what binds us all together is our strong rejection of the "traditional" account that both Redish and Meltzer seek to defend. As I have shown in this rejoinder, neither "traditionalist" presents a careful and integrated counternarrative of the "traditional" position that comes within miles of the required level of coherence and plausibility. Meltzer contents himself with "easy" answers that are anything but, and Redish rewrites the text and refuses to seriously engage history, structure, and case law. In fairness to them, it must be noted that they were asked to respond to my ideas, not affirmatively set out their own from start to finish. But given that I have always explicitly framed the issue as a comparative question, their expositions fall far short.

The biggest problem is that nowhere else is the "traditional" account set forth and defended with rigor. Redish's comment cites his earlier work, but there is very little careful history here, and obviously no engagement of subsequent and more comprehensive accounts that Clinton and I have offered..$^{87}$ So too, Meltzer, in

86 See Amar, supra note 4, at 1506 n.18 (citing sources). Professor David Engdahl's comprehensive but largely unpublished work, which came to hand as the present essay was in press, also merits mention. Engdahl powerfully critiques the "traditional" account along lines that, in general, strongly support the two-tier thesis.

87 Nor does Redish's current comment improve matters. His citation of John Rutledge's remarks at Philadelphia actually undercuts his argument, as he indeed acknowledges. See Redish supra note 1, at $1646 \mathrm{n.49}$, and his only other historical arguments consist of wildly conclusory nonsequiturs concerning the Madisonian Compromise and the convention's decision to abandon a congressional negative in favor of a judicially enforceable supremacy clause. These issues are painstakingly addressed in both Clinton's work and my own, and Redish's treatment simply fails to address our arguments and evidence.

Redish also argues that although he and I both understand that federal-state judicial parity is a myth, perhaps the framers didn't. See id. at 1644 . The evidence Clinton and I present shows otherwise, and Redish neither engages this evidence nor presents contrary historical evidence. Professor Redish shows good structural intuition in seeing parity as a myth, but on this issue he is no smarter than the federalist framers themselves. 
explaining why he finds the "Tradition" more plausible, string cites three sources. Meltzer seems to view these sources as so decisive as to obviate the need for him to rehearse their arguments in detail and thereby demonstrate their comparative advantage. ${ }^{88}$ The first source is a one-page statement (citing next to nothing) from a 1965 lecture delivered by Profess.or Wechsler. ${ }^{89}$ The second source, a twelve page pre-Clinton-and-Amar symposium essay by Paul Bator, not only cites virtually no eighteenth or early nineteenth century sources in support of the "Tradition," but in fact identifies some of the major historical defects in the "traditional" account:

The "states rights" argument at the Constitutional Convention was that there was no need for lower federal courts precisely because the appellate jurisdiction of the Supreme Court would provide sufficient assurance of the supremacy and uniformity of federal law in cases decided by the state courts. It was the premise of this argument that the Supreme Court would have the power to review cases originating in the state courts concerning issues of federal law. It was plainly not contemplated that the system could work effectively with the state courts as courts of last resort on issues of federal law. ${ }^{90}$

Meltzer's final citation is to a 1984 essay by Professor Gerald Gunther. ${ }^{91}$ But as Meltzer himself notes elsewhere, ${ }^{92}$ Gunther's 1989 public statements are rather encouraging of the two-tier approach. Although Meltzer also cites private correspondence implying that there may be even more recent backsliding on Gunther's part, ${ }^{93}$ I take this correspondence to be a tribute to the artfulness with which Meltzer has packaged his skepticism of the two-tier thesis. ${ }^{94}$

88 See Meltzer, supra note 2, at 1624. Although Meltzer implies that space constraints preclude adequate presentation of the "traditional" account, id., I think the problem lies elsewhere. To my mind Meltzer would have been more persuasive had he spent less space on irrelevancies and moleholes-e.g., unimportant drafts from Philadelphia, the wrinkle of $\S 25$, and implications for parity beyond the jurisdiction-stripping debate-and more time pondering central elements of the twotier thesis like items $* 1-* 4$, and the generally mandatory nature of "shall."

89 Wechsler, The Courts and the Constitution, 65 Colum. L. REv. 1001, 1005 (1965).

90 Bator, Congrgressional Power over the Jurisdiction of the Federal Courts, 27 VILL. L. REv. 1030, 1038-39 (1982).

91 Gunther, Congressional Power to Curtail Jurisdiction: An Opinionated Guide to the Ongoing Debate, 36 Stan. L. Rev. 895 (1984).

92 See Meltzer, supra note 2, at 1569 n.2.

93 See id.

94 Indeed, I must confess that when I first read Meltzer's essay in draft, I too, began to doubt the two-tier thesis. But the more I examine Meltzer's presentation, the less doubtful I become on the key comparative question. 
In the end, hope springs eternal. I hope that I have shown that many of Meltzer and Redish's criticisms are exaggerated and that their affirmative arguments on behalf of their "Tradition" are woefully thin. I hope that when Professor Gunther reads this rejoinder he will once again see the light. Finally, I hope, dear reader, that you will accept the invitation of all of the essays in this volume to examine the evidence and arguments firsthand, and judge for yourself. And when you do, I hope that you, too, will see that the two-tier thesis plainly provides the most satisfying account of article III. 
